Portland State University

PDXScholar

Master of Environmental Management Project

Reports

Environmental Science and Management

$6-2010$

\title{
Outcomes of a One-week Teaching Training in Community-based Ecological Research
}

Kara Gonsler

Portland State University

Follow this and additional works at: https://pdxscholar.library.pdx.edu/mem_gradprojects

Part of the Environmental Education Commons

Let us know how access to this document benefits you.

\section{Recommended Citation}

Gonsler, Kara, "Outcomes of a One-week Teaching Training in Community-based Ecological Research" (2010). Master of Environmental Management Project Reports. 17.

https://pdxscholar.library.pdx.edu/mem_gradprojects/17

https://doi.org/10.15760/mem.21

This Project is brought to you for free and open access. It has been accepted for inclusion in Master of Environmental Management Project Reports by an authorized administrator of PDXScholar. Please contact us if we can make this document more accessible: pdxscholar@pdx.edu. 


\title{
Outcomes of a One-week Teaching Training in Community-based Ecological Research
}

\author{
By: Kala Gonsler \\ June 3, 2010
}

\begin{abstract}
Advisor: Marion Dresner
Community Partners: Lynn Vanderkamp \& Megan Hanson, Bureau of Environmental Services
\end{abstract}




\begin{abstract}
The goal of this project was to expand on potential audiences and partnerships within the Teaching Ecological Complexity Project, by creating a one-week teacher training workshop in collaboration with a local natural resource management partner. The training sought to increase teachers' understanding of ecology and qualitative conceptual models through immersion in field research and partnerships with local scientists and natural resource managers. Ecological knowledge was measured by comparing pre and post qualitative conceptual models, which were scored with a rubric and analyzed using the Wilcoxon Signed Ranks Test. Classroom implementation of an inquiry-based ecological research project was expected of participants. The teachers' level of inquiry-based teaching was assessed using pre and post workshop surveys, as well as a follow-up survey nine months later. These surveys were analyzed using the Wilcoxon Signed Ranks Test. The workshop was generally successful at producing the expected outcomes. However, some limitations existed in the workshop design, and from these, future recommendations for trainings are discussed.
\end{abstract}

\title{
Project Description and Relevance
}

High school ecology education is often taught indoor either through a textbook or a prescribed experiment for which the results are already known. Research has shown that students learn more and at a higher level when they are engaged in authentic inquiry-based science where they are outside in the field performing research to address an unanswered question (Barnett et al., 2006, Crawford, 2000, Gengarelly \& Abrams, 2009, \& Jeanpierre et al., 2005). Authentic inquiry-based science is strongly supported by both science education researchers and classroom teachers, yet the incorporation of it into classrooms is minimal. This lack of authentic inquiry-based science does not seem to be due to a lack of support from teachers (Gengarelly \& Abrams, 2009). Many teachers support the idea of authentic science research, yet a lack of adequate background content knowledge often deters them from involving their classes in this type of learning (Barnett et al., 2006, Darling-Hammond, 1999, Gengarelly \& Abrams, 2009, Slingsby, 2001, \& Talsma, 2001).

Another barrier preventing teachers from implementing authentic inquiry-based research is a lack of personal experiences of this type (Gengarelly \& Abrams, 2009, Slingsby, 2001). In 
college courses, teachers experience portions of the process of inquiry yet often do not complete an investigation from start to finish. Given that their experiences are limited to partial inquiry investigation, it is not surprising that teachers feel inadequately prepared to teach their students in this way (Gengarelly \& Abrams). It is critical that these teachers receive the proper training in inquiry-based research and background knowledge to give them the skills and the confidence necessary to engage their students in this higher-level science learning.

One way to address this lack of knowledge and confidence is to provide effective teacher training programs (Barnett et al., 2006, Gengarelly \& Abrams, 2009, Talsma, 2001). Through teacher trainings, teachers can strengthen their understanding of how to do authentic inquirybased research, while also expanding their science content knowledge. While teacher training programs vary depending on the provider's and the audience's needs, there are some recurring elements in effective teacher training programs.

\section{Inquiry-based Research}

Inquiry-based research provides teachers with the opportunity to engage in forming a research question, collecting and analyzing data, and interpreting and presenting the results (Gengarelly \& Abrams, 2009, Slingsby, 2001). In order to create their own testable research question, teachers must develop a deep understanding of the ecosystem that they are studying. Their ecological knowledge of the system further increases as they research the system and collect and analyze data. Interpreting the results is an especially critical step, as it engages higher order thinking skills and synthesizes the steps of the research process. This experience actively engages teachers in the process of scientific research and demonstrates the process of inquiry-based learning that students will engage in. Through this experience teachers can gain skills and knowledge that are necessary for classroom implementation (Shepardson et al., 2002). 


\section{Reflective Use of Qualitative Conceptual Modeling}

Using qualitative conceptual models in conjunction with ecological training strengthens the learning that participants experience. "Qualitative conceptual model" is a term coined by the Teaching Ecological Complexity project, and is a combination between two other types of modeling, qualitative ecological modeling and concept mapping (Dresner \& Elser, 2009). A qualitative conceptual model is a representation of a participant's understanding of an ecological system. It shows the main components present in a system and the links between them. The models are paired with essay questions (Figure 3), which require the participants to explain their representation of the ecological system (Dresner \& Elser, 2009). Qualitative conceptual models can be used as a reflective tool to represent a participant's understanding at a given moment and help them to critically examine their prior knowledge and identify any missing links or misconceptions they may have. This step of reflection is a necessary link between a learning experience and making meaning from that experience (Fiddler \& Marienau, 2008, Meichtry \& Smith, 2007, Van Driel \& Verloop, 2002). Once their understandings have been examined, the prior simplified understandings that teachers held can be replaced by more accurate and complex explanations (Greca \& Moreira, 2000).

\section{Scientific Content Knowledge}

A deep understanding of scientific knowledge is an important component in preparing teachers to do authentic ecological research with their students. Research continues to show that student achievement is highly dependent on teacher expertise and that teaching is most effective when the teacher knows well beyond the level of content knowledge they are required to teach (Darling-Hammond,1999, Henze et al., 2007, Van Driel \& Verloop, 2002). Insufficient scientific knowledge often leads to a more superficial approach to teaching science, focusing on 
memorization and recall. Often, less class time is dedicated to teaching science overall (Shallcross et al., 2002). This depth of knowledge can be effectively developed during trainings through scientific literature and experiences, and through interaction with experts in the field (National Research Council, 1996b)

Pedagogical Content Knowledge

Pedagogical Content Knowledge is also an important component to include in teacher training workshops. Shulman describes Pedagogical Content Knowledge as the combination between subject content knowledge and pedagogy, the knowledge of how to teach a particular subject (1987 as cited in Shallcross et al., 2002). Pedagogical Content Knowledge addresses issues specific to science teaching and provides the connection between the content that teachers learn and how they will apply it in their classrooms. Some of the issues in science Pedagogical Content Knowledge include addressing both substantive knowledge, "Knowing it" and syntactical knowledge, "Knowing how" (Shallcross et al., 2002). In science education, it is critical that not only content knowledge is emphasized, but that knowledge of how to do something, such as the research process, is also focused on.

Science Pedagogical Content Knowledge also requires teachers to be aware of the prior knowledge their students have when they come into their classroom. This prior knowledge acts as the base upon which further understanding is built. It is important that teachers know what knowledge their students already have, as well as what misconceptions might exist (Shallcross et al., 2002). These misconceptions must be addressed and corrected, otherwise they may become engrained as a part of the learner's understanding. 


\section{Research Project and Questions}

To encourage the use of inquiry-based research in local classrooms, I partnered with the city of Portland's Bureau of Environmental Services to provide a weeklong workshop to teachers during the summer of 2009. This training was intended to provide teachers with the opportunity to learn more about local watershed ecology issues while learning skills necessary to complete an inquiry-based research project. The workshop was planned for only five days, so the amount of time and information that could be covered was very limited. We used our experiences from the Teaching Ecological Complexity program, the program from which this training originated, to plan additional details of the schedule.

Teaching Ecological Complexity was a professional development program that was funded by the National Science Foundation, and was ongoing from 2006-2010 at five Long Term Ecological Research sites (LTERs) across the country. The purpose of this program was to train middle and high school science teachers to do inquiry-based ecological research, which they were then expected to implement in their classrooms. Teaching Ecological Complexity included an immersion in inquiry-based field research, as well as the use of reflective qualitative conceptual modeling. The professional development programs usually lasted two weeks, and in some cases were residential programs where teachers stayed at the LTER site for the two weeks. During this time, teachers were supported by scientists who were involved in research similar to the topics of their own investigations.

From the Teaching Ecological Complexity program, three primary components of professional development were chosen as the basis for our training. We chose to emphasize those related to science content knowledge, including inquiry-based research, qualitative conceptual modeling, and ecological content knowledge. By immersing participants in inquiry-based 
research, we aimed to provide a more complete experience with each step of the research process. We sought to increase the teachers' understanding of the scientific research process, while also increasing their confidence in conducting research.

This process typically takes longer than the five days that we had planned for. For example, the professional development workshop discussed in Shepardson et al. consisted of a two-day preparation workshop, either a two or three-week workshop, depending on site choice, and additional extension workshops throughout the following year (2002). Barnett et al.'s main workshop lasted only a week, however it also included a one day kick-off meeting before classes started in the fall, as well as two one-day follow-up workshops each semester of the next school year (2006). Past workshops within the Teaching Ecological Complexity program typically lasted for two weeks, and included extended workdays since the teachers lived on site during that time (Dresner \& Elser, 2009). Given the busy schedule and many time commitments of teachers, we used this opportunity to see how effective the process could be when condensed into a shorter time period. It was expected that a one-week workshop would be sufficient to increase teachers' ecological knowledge and confidence in doing inquiry-based research. The primary research question asked,

“Can a one-week workshop increase teachers' ecological knowledge and confidence in doing inquiry-based research?”

A secondary hypothesis was that this increase in confidence and knowledge would lead to the use of inquiry-based research in the teachers' classrooms. To address this, we asked, "In the year following the workshop, did teachers implement an inquiry-based research project in their classes?" 


\section{Developing a Collaborative Partnership with the Bureau of Environmental Services}

Portland Oregon is a city known for its large amount of urban natural areas and environmental attitudes. With over 7,000 acres of natural area protected from development, including over 5,000 acre Forest Park, there are opportunities around the city to experience nature while in the urban environment (Portland Parks and Recreation, 2006). This makes it relatively easy to find study sites with varying degrees of "natural" verses "disturbed" characteristics, providing comparison sites for ecological research projects. The Bureau of Environmental Services maintains and manages many of these sites, and has had a big role in getting students to appropriate sites for ecological research. With the many opportunities this city provides, it is important that teachers are equipped with the knowledge, skills, and confidence needed to involve their students in ecological research.

The department of the Bureau of Environmental Services (BES) that is generally responsible for education and outreach is called the Clean Rivers Education program. This program offers a variety of lessons aimed at informing K-12 students about local watershed ecology issues. The Clean Rivers Education program has occasionally offered teacher training programs in the past, but not in recent years. Beginning in the fall of 2008, I met with Lynn Vanderkamp and Megan Hanson of the Clean Rivers Education program to discuss a collaboration to offer a teacher training program the following summer. We decided that we would offer an inquiry-based watershed ecology workshop in July 2009. Throughout the year, we remained in close contact through email, and met approximately every other month.

Once we decided upon an inquiry-based watershed ecology workshop, the next step was to determine which specific research topics would be offered. To make this decision, many things had to be taken into consideration. First, we wanted to offer topics that would be of 
interest to teachers. We began by listing the various research topics that teachers had shown interest in while working with Lynn and Megan. From there, we decided which topics we were prepared to offer at the training. We narrowed the list down to topics that we had appropriate resources for, including necessary equipment and support from research scientists. We held a meeting with prospective participants and asked them which of the topics they were interested in studying. Using their feedback, the list was narrowed to two topics, a comparison between water bodies using macroinvertebrate and water chemistry sampling, and a comparison study between wetlands and human implemented water management systems, bioswales. The following months were spent coordinating logistics, including determining study site locations, confirming details of the schedule (Figure 8), and lining up scientists to support the teachers through the research process.

\section{Recruitment of Participants}

When deciding how to recruit teachers for the training, two main criteria were identified. First, teachers were required to have taken some upper level courses in science at some point in their careers. This basic level of background knowledge was critical to ensuring that workshop time was used most efficiently. Most high school science teachers easily met this requirement, since most of their college training programs required a significant amount of science content as a part of the high school educator curriculum. Middle school teacher applicants also had significant background knowledge in the sciences.

The second criteria was that the teachers must have worked with the city of Portland's Bureau of Environmental Services (BES) in past classroom education effort. It was important that our group of participants was committed to the project and would follow through in applying what they learned in the training to their classroom projects. By involving teachers who had 
shown that commitment in the past, we felt we had a better chance of getting that commitment again. This was only somewhat successful and is discussed in further detail below.

Once a group of teachers meeting these criteria had been identified, they were invited to attend an informational meeting where they could receive more details about the training and could ask any questions that they had. Following the meeting, teachers were asked to submit an application if they were interested, by answering the questions on the second page of the informational flyer (Figure 1). By submitting the application, they committed to attending the training and became a part of the official list of participants for this program in July 2009.

\section{Description of the Participants}

The teachers were from various schools within the Portland Public Schools district, with the exception of two non-traditional environmental educators from Tryon Creek State Park. Two teachers taught high school, and four taught at middle schools, therefore grade levels ranged from sixth through twelfth grade. Since all participants were science teachers, they came in with some background experience in science, providing them with a base of prior knowledge as a starting point. The teachers taught a variety of subjects, including environmental, earth, physical, and life sciences, biology, science and technology, and service learning, One teacher taught at a dual language school where all subjects were taught in French and English, and another taught classes that had one-third of the students speaking English as their second language. There were also two teachers from "Title 1" low-income schools.

\section{Overview of the Workshop:}

This one-week workshop took place at Zenger Farm in Portland, Oregon. The goal was to involve teachers, and eventually their students, in monitoring and understanding issues of watershed ecology in their local environment. There were two different research groups, each 
investigating a different topic. One group's study focused on comparing natural wetlands with human implemented water management systems, bioswales. The other group focused on comparing three different water bodies' water quality measurements, through data collection including macroinvertebrate sampling and various water chemistry measures. For each of these projects, the teachers worked through the inquiry process by creating a hypothesis, collecting and analyzing data, interpreting the statistical results, and communicating their findings in a research poster. The teachers prepared a group research poster and presentation.

\section{Methods}

The primary research question was, "Can a one-week workshop increase teachers' ecological knowledge and confidence in doing inquiry-based research?" Change in teachers' ecological knowledge was measured using qualitative conceptual models. At the beginning of the training, teachers created qualitative conceptual models to show their current ecological understandings. To create a qualitative model, teachers first identified the key variables that were present in their ecosystem of study. For example, in the stream ecology study, teachers listed important biotic variables, including various types of macroinvertebrates, vegetation, and bacteria, as well as abiotic factors, including light, water chemistry measures, temperature, and substrate type. Next, symbols were added to show the connections between each of these variables (as described in Figure 2). After drawing the models, the teachers answered a series of essay questions (Figure 3) to further explain the connections between the variables. These questions probed their thinking and encouraged them to support their ecological ideas with examples from their model. Following individual completion, teachers formed small groups with one or two others and shared their thinking about their experiments as expressed in their essays and models, through "Think-Pair-Share." Reflective discussion and collaboration with peers is 
an important component of the learning process in professional development (Shallcross et al., 2002, Van Driel \& Verloop, 2002). The "Think-Pair-Share" exercise provided the teachers with time for collaboration and gave them the opportunity to articulate their ecological understandings, as shown in their models.

This process was repeated at the end of the training to give teachers the opportunity to reflect on what they had learned about ecological systems. For each teacher we had a model and set of essay questions from both the beginning and the end of the program. The models were scored and compared as a pre/post assessment to show level of growth in understanding. The reflective essay responses were used in conjunction with the actual models to illustrate the ecological connections that were shown. Rubrics were used to score the qualitative conceptual models. Using the specified rubric (Figure 4), two evaluators independently scored the models and essay questions. Once both had their individual scores, they went through each question and compared their scores with the other evaluator's. If they had both given the same score for a particular question, that score was accepted. If there were variance between their scores, they would each explain the reason for giving their score. They would discuss the differences and then come to a conclusion about which score was the most accurate.

The second assessment tool that addressed the question, "Can a one-week workshop increase teachers' ecological knowledge and confidence in doing inquiry-based research?" was a Teacher Classroom Practices Survey (Figure 5). The survey was used to measure any change in teachers' confidence in doing inquiry-based research. It included questions about the teachers' confidence and comfort level of implementing an ecology research project with their students, as well as their use of the various practices of inquiry in their classrooms. The survey was given at the beginning of the training, as one of the first activities on the first day, and was given again at 
the end of the training on the last day. When the survey was given on the first day, it asked what practices teachers had had during the past school year. When given on the last day, it asked teachers to speculate what their practices would be in the upcoming year. These responses offered insight into teachers' confidence level with each practice. A response showing that they planned to increase how often they take students outside, for example, would suggest that the teachers' confidence in doing this practice had increased. To follow up on the teachers' actual classroom practices, the survey was also emailed to the participants nine months after the training. The survey results from the beginning of the workshop were compared to the results from the end of the workshop, and also from the survey given nine months after the training.

Group interviews were conducted the last day of the workshop to gain additional information about teachers' ecological knowledge and confidence levels, as shown through the qualitative conceptual models and survey responses. Teachers were broken into two groups, based on their topic of study. They were asked to discuss their understanding of their research projects, using their models as a reference. The interviews also provided an opportunity for teachers to elaborate on their responses to the surveys. They served as a summarization of their perceptions of the workshop's impact on their ecological understandings.

Feedback on the workshop's strengths and weaknesses was also needed. It was important for us to hear from the teachers about what was most useful for them, as well as what could be improved upon. A workshop evaluation survey was administered at the end of the workshop.

Finally, the researcher worked with one teacher's classes during the following school year. Observational notes were taken during each visit to the classroom, which occurred approximately once a month. The three classes took the Student Science Interest Survey (Figure 7) near the beginning of their research project in November, and again at the completion in the 
beginning of May. This survey was intended to be a measurement of increased student interest in science as a result of the long-term research project.

\section{Results:}

\section{Qualitative Conceptual Models}

The qualitative conceptual model scores were analyzed by grouping the pre-workshop scores and the post-workshop scores for each question and using the Wilcoxon Signed Ranks test to identify any significant differences between the pre and post scores. This statistical test has been used in a variety of studies that have assessed changes in participants' confidence, attitudes, or practices, before and after an educational program (Dresner \& Elser, 2009, Ericksen, 2005, \& Yarrow, 2006). The Predictive Analytics SoftWare Statistics 17 (PASW 17) version of SPSS was used to run the Wilcoxon Signed Ranks test. Model questions one through four showed a significant difference $(\mathrm{p}<0.025)$ between the pre-workshop and post-workshop scores (Table 1$)$. Though these scores did significantly improve, there were few scores of "4" showing mastery of the concept. Particularly question four, which involved creating a testable hypothesis, had no participants master the concept.

Table 1: Wilcoxon Signed Ranks Test results for pre-workshop and post-workshop modeling scores. Also, number of " 4 " scores showing mastery for each question. See attached rubric (figure 4) and essays (figure 3) for detailed questions.

\begin{tabular}{|l|c|c|c|c|c|c|}
\hline & N & P-value & $\begin{array}{c}\text { Average } \\
\text { Pre } \\
\text { Score }\end{array}$ & $\begin{array}{c}\text { Number of “4” } \\
\text { Pre }\end{array}$ & $\begin{array}{c}\text { Average } \\
\text { Post } \\
\text { Score }\end{array}$ & $\begin{array}{c}\text { Number of "4" } \\
\text { Post }\end{array}$ \\
\hline $\begin{array}{l}\text { Question 1: Model } \\
\text { Components }\end{array}$ & 8 & 0.02 & 2.375 & 1 & 3.25 & 3 \\
\hline $\begin{array}{l}\text { Question 2: Model } \\
\text { Connections }\end{array}$ & 8 & 0.02 & 2.375 & 1 & 3.25 & 2 \\
\hline $\begin{array}{l}\text { Question 3: } \\
\text { Diversity }\end{array}$ & 8 & 0.005 & 2.125 & 0 & 3.125 & 2 \\
\hline $\begin{array}{l}\text { Question 4: } \\
\text { Hypothesis }\end{array}$ & 8 & 0.014 & 1.875 & 0 & 2.625 & 0 \\
\hline
\end{tabular}




\begin{tabular}{|l|l|l|l|l|l|l|}
\hline $\begin{array}{l}\text { Question 5: } \\
\text { Feedback }\end{array}$ & 8 & 0.157 & 2.25 & 1 & 2.75 & 2 \\
\hline
\end{tabular}

Though the qualitative conceptual models showed significant improvement for four of the five questions, the use of models on their own only gives us a certain degree of understanding of what teachers learned. It is important that the models are used as a reflective tool, and that teachers are able to explain the models in the essay questions, as well as in interviews. In the group interviews at the end of the workshop, teachers often referenced their models as an example of what they had learned. The teachers were able to speak about their ecological knowledge in a more authoritative way than they had at the beginning of the workshop. They discussed issues of complexity with much more confidence than previously expressed. When the teachers discussed their final research projects, they used examples from their research to support their statements. This was impressive given that the discussions at the beginning of the workshop were highly speculative and unfocused.

Although the models provided a reference point for teachers to discuss their learning, there is a limitation to how much the models can express themselves. A model shows the teachers understanding at a given moment in time, but may not encompass the extent of their knowledge. This became particularly apparent with the group of teachers studying bioswales. In discussion, they expressed a solid understanding of ecological concepts, particularly feedback in a system. They discussed feedback mechanisms in bioswales, between plants, microbes, and soil development. However, their models were comprised of mostly abiotic factors, and by themselves did not show much knowledge of ecological relationships and complexity.

Scores from the pre and post models also revealed a small number of " 4 ," scores of mastery. Though teachers showed increases in their ecological knowledge compared to the 
beginning of the workshop, most did not master the concepts presented. The presence of scientists experienced in working with teachers would have potentially helped teachers to reach the level of mastery in their ecological understandings. During the workshop, the teachers had support from some very knowledgeable and helpful $\mathrm{PhD}$ students, expert in their areas of study, but with little past experience working with teachers. Because of this, the emphasis on mastering concepts such as creating a testable hypothesis and understanding feedback might have been deemphasized, with the focus more heavily on the research itself and the protocols.

\section{Teacher Practices Survey}

Teacher practices surveys were analyzed by grouping pre-workshop, post-workshop, and scores from later in the academic year, 'spring' for each question. PASW 17 SPSS was used to run the Wilcoxon Signed Ranks test on the data, to identify differences between pre-workshop and post-workshop surveys, as well as pre-workshop and 'spring' surveys. The question regarding 'going into the field to collect data related to questions posed' was the only one with a score that was significantly different between pre-workshop and post-workshop surveys ( $\mathrm{p}<$ 0.025). (Table 2).

Table 2: Wilcoxon Signed Ranks Test results for pre-workshop and post-workshop Teacher Practices Survey scores, also pre-workshop and spring survey scores.

Indicate the degree to which students do the following for this project:

\begin{tabular}{|l|c|c|c|c|c|c|}
\hline & $\mathrm{N}$ & $\begin{array}{l}\text { pre-score } \\
\text { average }\end{array}$ & $\begin{array}{l}\text { post-score } \\
\text { average }\end{array}$ & $\begin{array}{l}\text { spring } \\
\text { score avg }\end{array}$ & $\begin{array}{l}\text { p-value } \\
\text { pre-post }\end{array}$ & $\begin{array}{l}\text { p-value } \\
\text { pre-spring }\end{array}$ \\
\hline 1. form a hypothesis & 8 & 3.38 & 4.29 & 3.75 & 0.131 & 0.157 \\
\hline 2. design a study & 8 & 2.50 & 4.00 & 3.25 & 0.026 & 0.059 \\
\hline 3. collect data & 8 & 3.88 & 4.43 & 4.25 & 0.336 & 0.655 \\
\hline $\begin{array}{l}\text { 4. enter data on } \\
\text { spreadsheets }\end{array}$ & 8 & 2.38 & 3.00 & 3.25 & 0.317 & 0.046 \\
\hline 5. analyze data & 8 & 3.00 & 4.14 & 3.50 & 0.066 & 0.705 \\
\hline 6. interpret data & 8 & 3.50 & 4.14 & 3.50 & 0.257 & 0.705 \\
\hline 7. write research reports & 8 & 2.63 & 3.71 & 2.75 & 0.084 & 0.180 \\
\hline 8. present and discuss the & 8 & 3.13 & 4.29 & 3.50 & 0.047 & 0.157 \\
\hline
\end{tabular}




\begin{tabular}{|c|c|c|c|c|c|c|}
\hline $\begin{array}{l}\text { meaning/importance of } \\
\text { results }\end{array}$ & & & & & & \\
\hline $\begin{array}{l}\text { 9. work with an outside } \\
\text { agency or scientist }\end{array}$ & 8 & 2.75 & 4.14 & 3.75 & 0.072 & 0.180 \\
\hline $\begin{array}{l}\text { 10. learn about the } \\
\text { environment and local } \\
\text { ecology }\end{array}$ & 8 & 3.75 & 4.40 & 4.00 & 0.129 & 0.655 \\
\hline $\begin{array}{l}\text { 11. learn that science is a } \\
\text { way to raise questions and } \\
\text { seek answers }\end{array}$ & 8 & 4.00 & 4.60 & 4.00 & 0.083 & 0.317 \\
\hline $\begin{array}{l}\text { 12. go into the field to } \\
\text { collect data related to } \\
\text { questions they posed }\end{array}$ & 8 & 2.88 & 4.14 & 3.75 & 0.024 & 0.276 \\
\hline $\begin{array}{l}\text { 13. conduct long-term ( } 2 \text { or } \\
\text { more weeks) experiment }\end{array}$ & 8 & 2.13 & 4.14 & 3.75 & 0.027 & 0.102 \\
\hline $\begin{array}{l}\text { 14. work in teams to } \\
\text { conduct field research }\end{array}$ & 8 & 2.75 & 4.14 & 3.75 & 0.071 & 0.083 \\
\hline $\begin{array}{l}\text { 15. assess their own work } \\
\text { using rubrics }\end{array}$ & 8 & 2.50 & 3.71 & 3.00 & 0.071 & 0.197 \\
\hline $\begin{array}{l}\text { 16. demonstrate their } \\
\text { understanding about the } \\
\text { relationship between } \\
\text { evidence and conclusions }\end{array}$ & 8 & 2.50 & 4.00 & 3.00 & 0.026 & 0.102 \\
\hline 17. learn ecology concepts & 8 & 3.50 & 4.14 & 4.00 & 0.157 & 1.00 \\
\hline $\begin{array}{l}\text { 18. learn how to draw an } \\
\text { ecological model } \\
\text { illustrating inter- } \\
\text { relationships }\end{array}$ & 8 & 2.00 & 4.00 & 3.00 & 0.027 & 0.357 \\
\hline $\begin{array}{l}\text { 19. use the internet to } \\
\text { facilitate their research } \\
\text { project }\end{array}$ & 8 & 3.25 & 3.86 & 3.00 & 0.336 & 0.785 \\
\hline
\end{tabular}

Though the teacher practices survey showed significant differences between the preworkshop and post-workshop survey for only one of the 19 questions, the average score for all questions increased. There were no significant differences between the pre-workshop and spring survey responses, but the average score for 16 of the 19 questions increased. Both of these surveys have their limitations, which helps to explain the discrepancy between the two. The post survey was taken at the end of the workshop, before the school year had begun. Teachers responded to this survey based on what they planned to do with their students during the school 
year. Average scores for all questions increased, suggesting that the teachers felt more confident and prepared to include each of these practices. However, these responses were speculative, so actual follow-though varied from these responses.

To gain a more accurate knowledge of what occurred throughout the year, the same survey was sent out nine months after the workshop. At this point, teachers had completed most of their school year and could respond based on their actual implementation, rather than speculation. Unfortunately, only four of the eight teachers responded to this survey. Though their responses more accurately reflected their implementation through the year, we are limited by only having a 50\% response rate. The responses of these four did show increase in average scores for 16 of the 19 teaching practices. For the participants who responded to the teacher practices survey in the spring, increases in inquiry practices did occur in their classroom, though not to a statistically significant level.

\section{Group Interview}

In the group interview responses, recurring themes emerged. Similar responses were listed together and sorted by theme. These themes are described below and are supported by specific teachers' quotes. Teachers attributed their shifts in understanding to the combination of using qualitative conceptual models to think about the experiment and having experts on hand to provide the detail needed to build a good experiment. By learning the scientific sampling techniques and personally going through the research project, they became more confident in their individual skills in conducting research. By being put into that environment, the "research became an interactive, hands on, personal experience". Peer collaboration and discussion were also cited as important factors. 
Teachers felt that the benefits of the research project itself were, "It helped us get beyond the theoretical and into actual experiment" and "It got us out doing the research." The project helped teachers to see the different influential components, look for relationships, and even, "Find some we hadn't thought about." One teacher stated, "By taking measurements and seeing things visually, we learned how to look at stuff." Another said, "It gave me more confidence to conduct research with students in the field." This suggests that the process of completing each step of the research project helped teachers to feel more confident in having their students do the same.

Both groups of teachers found the qualitative conceptual models to be helpful in guiding them to form a question. One teacher stated that, "A model forces you to see where you are making assumptions. It helps you figure out how you will test your question.” Another said that, “Until you're forced to put on paper, you don't really understand/formalize your thoughts, the process of writing it helps to clarify ideas and your understanding of the system." Along with the research project, the models were also said to help highlight all components that are important to system, and that otherwise important factors may be left out. They helped the teachers to examine whether two factors have positive, negative, or neutral influences on each other, and to look at the system as a whole. Another teacher stated that, "The models represent something incredibly complex, every model has strengths and limitations-it gets you thinking about complexity and how things could be represented, so even limitations are useful." This teacher continued, stating that she felt more confident in discussing ecological systems and their components, and that she expanded her understanding of science inquiry and how to model ecosystems. 


\section{Workshop Evaluation Survey}

Teachers also completed a workshop evaluation survey (Figure 6), providing feedback about the strengths and weaknesses of the workshop. The survey asked teachers to rank their responses from lowest, " 1 = Strongly disagree," to highest, "5 = Strongly agree". The highest ranking questions were, "As a result of my participation in the Teaching Ecosystem Complexity Workshop, I plan to implement a unit where students will conduct an inquiry-based ecology field research project," with an average score of 4.7 , and "Rate how well the workshop prepared you to use field research," with an average score of 4.75 (Table 3). These results suggest that a strength of the workshop was preparing teachers to do research themselves. It also suggests that at the end of the workshop, they felt confident that they would be able to implement an inquirybased ecological research project with their students. The lowest score on the survey was found to be," Rate your level of satisfaction in preparing you to incorporate the workshop experiences into your science course," with an average score of 3.75. A couple teachers stated that they were still unsure about how to incorporate the modeling material into their courses.

Table 3: Workshop Evaluation Survey average scores.

\begin{tabular}{|l|c|c|}
\hline & N & Average Score \\
\hline 1. I am more knowledgeable than before about ecology content & 8 & 4.13 \\
\hline $\begin{array}{l}\text { 2. I am more knowledgeable than before about carrying out field } \\
\text { research }\end{array}$ & 8 & 4.50 \\
\hline $\begin{array}{l}\text { 3. I plan to implement a unit where students will conduct an } \\
\text { inquiry based ecology field research project }\end{array}$ & 8 & 4.70 \\
\hline $\begin{array}{l}\text { 4. I plan to implement one or more of the topics and/or skills I } \\
\text { learned this week }\end{array}$ & 8 & 4.50 \\
\hline 5. Ability to use field research & 8 & 4.75 \\
\hline 6. Ability to utilize modeling & 8 & 4.00 \\
\hline $\begin{array}{l}\text { 7. Organization of the workshop (presentations, mix of activities, } \\
\text { etc.) }\end{array}$ & 8 & 4.00 \\
\hline
\end{tabular}




\begin{tabular}{|l|c|c|}
\hline 8. Presentations by instructors & 8 & 4.00 \\
\hline 9. Support from instructors & 8 & 4.00 \\
\hline 10. Field work experience & 8 & 4.50 \\
\hline $\begin{array}{l}\text { 11. Preparing you to incorporate the workshop experience into } \\
\text { your science course }\end{array}$ & 8 & 3.75 \\
\hline $\begin{array}{l}\text { 12. Meeting the goals you had for your own learning about } \\
\text { ecological complexity }\end{array}$ & 8 & 4.50 \\
\hline
\end{tabular}

\section{Follow-through}

In the year following the workshop, the level of implementation of inquiry-based ecological research incorporated in teachers' classrooms was not as expected. Of the eight participants, four did not complete a project, four did, but only one worked with the researcher. The three who completed a project but did not work with the researcher stated that their classes completed inquiry-based research projects. These studies included investigations comparing wetlands and bioswales, monitoring of macroinvertebrate populations in an on-campus stormwater garden, and monitoring of riparian vegetation, stream flow and water quality at various sites around Portland. Since the researcher was not involved with these classes, the complete implementation of an ecological inquiry-based research project cannot be confirmed. This information is based on the teachers' statements.

\section{Case Study}

Only one teacher out of the group of eight worked with the researcher throughout the school year. She implemented an inquiry-based research project for each of her three classes, including amphibian monitoring, bioassessment of water quality, and riparian restoration and vegetation monitoring. All of the students were expected to do their ecological research within these overall topics, yet they were held responsible for creating their own research question and 
hypothesis. They collected data, analyzed and interpreted their findings, and found literature to support their conclusions. At the end of the year, the students created a research paper and poster, and presented their findings at the school's annual science fair.

As mentioned above, the three classes took the Student Science Interest Survey (Figure 8) near the beginning of their project in November, and again at the completion in the beginning of May. Using the Wilcoxon Signed Ranks test, significant differences between the pre-research project and post-research project surveys were not found. Though the Student Science Interest Survey did not show any significant changes, this teacher said that she had seen improvement in her students' ability to formulate research questions. She stated that her personal understanding of inquiry-based science had greatly increased throughout the year. She mentioned that, "It was especially difficult at first, trying to educate myself on all of the current issues within the topics that my students were researching. It was hard taking on three new projects all within one year, but I think in each following year it will get easier." When discussing the workshop, she stated, "I met lots of people who supported me throughout the year as I tried to incorporate more authentic inquiry into my classes. The students enjoyed working with these scientists and getting out in the field to do 'real' science."

Though we do not have comparison work of the students' from the beginning of the year, their final research projects did show a sophisticated level of ecological understanding. All three classes, sixth, seventh and eighth, created and presented research posters with a hypothesis and research question, methods, data analysis, graphs and tables, discussion, conclusion, and a section on future research ideas. These students researched their topics and used the literature to inform and explain their results. The eighth graders used qualitative conceptual modeling at the beginning of their projects to help them formulate their hypotheses. 
Hypotheses were refined throughout the research process and students showed an increase in ability to create testable hypotheses. One student began the project asking, "Where are most tadpoles found?" At the completion of his research project, the student asked, "How does human traffic affect amphibian tadpole and larvae populations?" His hypothesis was, "Tadpole Pond (in Oaks Bottom) is open to the public, therefore amphibian tadpoles and larvae populations will be smaller here than at Aurora Lake."

In discussions with students about their research, many cited their outdoor experiences as being helpful in the development of their research project. Students studying amphibians refined their hypotheses as they collected more data and began to notice more factors that might be important to look at. Some students were unable to collect enough field data to base their projects entirely on it. These students added an on-site plant study to their research. Field trips earlier in the year were credited as the primary factor in plant choice for their projects. The students said that working with the plants gave them a better knowledge of the plant characteristics, how to identify them, and how well they might survive in different environments. One student said that, "I had never thought about how important plant diversity is. We need certain plants as ground cover, certain ones do better by streams and wet areas, and certain larger plants are habitat for wildlife. One or two kinds of plants couldn't do everything at once." This appreciation of biodiversity is important for middle school students to understand, and will hopefully continue to develop more deeply in future ecology courses.

\section{Discussion and Recommendations}

Returning to the question, "Can a one-week workshop increase teachers' ecological knowledge and confidence in doing inquiry-based research," we find that it can. The qualitative conceptual model scores indicate a significant increase in teachers' ecological knowledge for 
four out of five questions. Teachers' responses from the group interview also cite an increase in understanding as a result of qualitative conceptual modeling. During the interview, teachers stated that the process of modeling helped them to form research questions and to create an experimental design to test their questions. In future one-week workshops, it is recommended that BES continue to include qualitative conceptual modeling as a critical component. To optimize teachers' learning through qualitative conceptual models, it is suggested that modeling be further incorporated into each day of the workshop. During this workshop, models were only used at the beginning and the end of the week. Future workshops should require teachers to modify and add to their models every night as homework. This is expected to improve the connection between modeling and each part of the research process, rather than just the first and last steps.

The process of completing a research project was also cited as a key contributor to teachers' increase in ecological knowledge and confidence in doing inquiry-based research. Workshop evaluation responses suggest that teachers felt confident doing field research and planned to implement an inquiry-based ecological research project with their classes. Group interview responses also show that teachers gained a better understanding of important components and relationships within their ecosystems of study, as a result of going through the research process. The teachers' responses state that they felt confident involving students in this type of research, after having gone through the process themselves. The teacher practices survey results also support the finding that teachers' confidence in doing inquiry-based research increased. As described above, there was an increase in all average scores from pre-workshop to post-workshop, suggesting that teachers were more confident with the implementation of an 
inquiry-based research project after the workshop. Though these results were not statistically significant, they show that teachers' confidence increased to a degree.

It is recommended that BES continue to include inquiry-based research as a primary component of future workshops. This past summer, we had only one day devoted to data collection, which limited the amount of data that could be collected, as well as the variety of sites that could be visited. In the future, it is recommended that at least two days be allotted to fieldwork and data collection. These days should ideally be scheduled with a literature research day in between, since research papers may provide teachers with ideas of additional data that should be collected. This additional data collection may provide teachers with the opportunity to address their research questions more completely.

Another recommendation for future workshops is that a scientist who is experienced in working with teachers be included in the workshop. As mentioned above, teachers showed increases in their ecological knowledge compared to the beginning of the workshop, yet most did not master the concepts presented. Scores from the pre and post models revealed a small number of " 4 ," scores of mastery. The presence of scientists with experience working with teachers is recommended, to help teachers to reach the level of mastery in their ecological understandings. Group interview responses also indicated that support from experts was beneficial, so increasing this support in future workshops is expected to further increase mastery of concepts.

Despite these increases in teachers' knowledge, confidence, and intentions to implement inquiry into their classrooms, in many cases this did not occur. Returning to the secondary question, "In the year following the workshop, did teachers implement an inquiry-based research project in their classes," we find mixed results. Four of the eight teachers stated that they implemented an inquiry-based research project, though the researcher can only personally 
confirm implementation by the one teacher with whom she worked. This leads to the question of why the teachers' increase in ecological knowledge and confidence in inquiry-based research did not transfer to the classroom. The workshop evaluation results may lend some insight into the mismatch between intentions and results. The lowest scoring response was, "Rate your level of satisfaction in preparing you to incorporate the workshop experiences into your science course," which suggests that the connection between the teachers' personal experiences and their incorporation into the classroom was not emphasized enough. This links back to the inclusion of pedagogical content knowledge in a teacher training workshop. Since our workshop time was limited, the decision was made to focus on the science content and not the pedagogical content knowledge. In retrospect, it seems that pedagogical content knowledge is another critical component that must be included in a teacher training workshop, if teachers are expected to incorporate what they learn into the classroom. BES should incorporate pedagogical content knowledge into future teacher training workshops, and can do so in a variety of ways. During the workshop, simulated teaching experiences should be included so that teachers can practice teaching others about what they've learned (Shallcross et al., 2002). This can be accomplished by having teachers create lesson plans to use with their classes, and teaching the lesson to the other participants. This allows teachers to collaborate with their peers in designing and modifying lessons. Simulated teaching experiences can also be included by inviting past workshop participants to demonstrate lessons that they have used with students.

Pedagogical content knowledge can also be included throughout the school year by offering group follow-up workshops (Shallcross et al., 2002). Mandatory follow-up workshops should be included as part of a teacher training program, to ensure that teachers continue to work on their pedagogical content knowledge throughout the school year. Each workshop can be 
based on an issue that teachers might face when implementing inquiry-based research projects into their classroom. These workshops can offer strategies for overcoming these issues, while providing opportunities for continued collaboration with experts and peers.

Lastly, support during the school year can play an important role in a teacher's ability to implement a research project (Barnett et al., 2006 \& Gengarelly \& Abrams, 2009). Two of the teachers who did implement a project expressed that the continued partnership with Portland State University and the Bureau of Environmental Services was instrumental in their ability to implement these projects. They said that the support in the classroom and at field sites made it possible to do more with their students than they would have been able to do previously. BES has provided support in the field and in classrooms for many years, and it is important that they continue to do so in the future.

\section{Additional Barriers to Follow-through}

Because of the lack of response from the teachers unable to follow-through, we cannot say exactly what prevented them from implementing a research project with their classes. However, the teachers that responded mentioned a few recurring barriers that certainly could have affected the other teachers. The most commonly cited barrier to implementation was a lack of transportation. Though teachers looked for sites within walking distance of their schools, it was not always possible to find one that fit their research needs. Some transportation funding was available to the teachers, but with a long-term project, adequate funding for repetitive visits was not provided. One teacher also mentioned a lack of equipment for the type of study that she wanted to conduct. She mentioned that she was able to borrow some equipment from PSU and BES, but that some projects required materials not available from either source. Another sited an issue with getting all of the other science teachers at his school on board. In his case, all classes 
are required to cover the same topics and projects in their classes, so for any project he implements he needs everyone else to agree to the same one. Lastly, maintaining student interest in projects was mentioned as a challenge for one teacher.

\section{Conclusion}

Considering that teachers did show increased ecological knowledge and confidence in doing inquiry-based research, the workshop did accomplish its goals to a degree. This project showed that a one-week workshop can be effective in increasing knowledge and confidence in a short amount of time. Also, four of the eight teachers successfully implemented some sort of inquiry-based ecological research project. These four teachers have worked to improve their instruction and their inclusion of inquiry in the classroom. In the future, they will hopefully continue in this direction and further increase their classroom use of inquiry-based ecological research.

Though the project was successful in these areas, there is still room for improvement. By including qualitative conceptual modeling, inquiry-based research, pedagogical content knowledge, and partnerships with experts and peers, future workshops are expected to be even more successful in meeting these goals. By incorporating these suggestions, a greater level of ecological understanding and confidence are expected, eventually translating to implementation of inquiry-based research projects in the classroom. The Clean Rivers Educators at BES are invaluable resources, and through their continued efforts and sustained partnerships with teachers, will reach these goals. 


\section{References:}

Barnett, M., Lord, C., Strauss, E., Rosca, C., Langford, H., Chavez, D., and Deni, L. 2006. Using the urban environment to engage youths in urban ecology field studies. Journal of Environmental Education. 37(2): 3-11.

Crawford, B.A. 2000. Embracing the essence of inquiry: new roles for science teachers. Journal of Research in Science Teaching. 37(9): 916-937.

Darling-Hammond, L. 1999. Educating teachers: The academy's greatest failure or its most important future? Academe, 85(1): 26-33.

Dresner \& Elser. 2009. Enhancing science teachers' understanding of ecosystem interactions with qualitative conceptual models. Teaching Issues and Experiments in Ecology. 6: 1-25.

Ericksen, D. 2005. An investigation into the effectiveness of a training program on student supervisors' self confidence. Thesis: North Carolina State University.

Fiddler, M. \& Marienau, C. 2008. Developing habits of reflection for meaningful learning. New Directions for Adult and Continuing Education. 118: 75-85.

Gengarelly, L.M. \& Abrams, E.D. 2009. Closing the gap: Inquiry in research and the secondary science classroom. Journal of Science Education Technology. 18: 74-84.

Greca, I.M. \& Moreira, M.A. 2000. Mental models, conceptual models, and modelling. International Journal of Science Education. 22(1): 1-11.

Henze, I., Van Driel, J.H., \& Verloop, N. 2007. Science teachers' knowledge about teaching models and modelling in the context of a new syllabus on public understanding of science. Research in Science Education. 37: 99-122.

Jeanpierre, B., Oberhauser, K., \& Freeman, C. 2005. Characteristics of professional development that effect change in secondary science teachers' classroom practices. Journal of Research in Science Teaching. 42(6): 668-690.

Manzanal, R.F., Barreiro, L.M.R., \& Jimenez, M.C. 1999. Relationship between ecology fieldwork and student attitudes toward environmental protection. Journal of Research in Science Teaching. 36(4): 431453.

Meichtry, Y. \& Smith, J. 2007. The impact of a place-based professional development program on teachers' confidence, attitudes, and classroom practices. Journal of Environmental Education. 38(2): 15-31.

National Research Council. 1996b. The role of scientists in the professional development of science teachers. Washington, D.C.: National Academy Press. 
Portland Parks \& Recreation. 2006. Natural Area Acquisition Strategy. http://www.portlandonline.com/shared/cfm/image.cfm?id=130583

Shallcross, T., Spink, E., Stephenson, P., \& Warwick, P. 2002. How primary trainee teachers perceive the development of their own scientific knowledge: links between confidence, content, and competence. International Journal of Science Education. 24(12): 1293-1312.

Shepardson, D.P., Harbor, J., Cooper, B., \& McDonald, J. 2002. The impact of a professional development program on teachers' understandings about watersheds, water quality, and stream monitoring. Journal of Environmental Education. 33(3): 34-40.

Shulman, L.S. 1987. Knowledge and teaching: Foundations of the new reform. Harvard Educational Review. 57(1): 1-22.

Slingsby, D. 2001. Perceptions of ecology: Bridging the gap between academia and public through education and communication. Bulletin of the Ecological Society of America. 82(2). 142148.

Talsma, V. 2001. The Rouge Education Project: Challenges of implementation. Journal of Environmental Education. 32(3): 26-30.

Van Driel, J.H. \& Verloop, N. 2002. Experienced teachers' knowledge of teaching and learning of models and modelling in science education. International Journal of Science Education. 24(12): $1255-1272$.

Yarrow, L.K. 2006. Food safety attitudes, beliefs, knowledge and self-reported practices of college students before and after educational intervention. Manhattan, KS. Thesis: Kansas State University. 


\section{Figure 1: Application for workshop}

To apply please include the following:

- Name, address, phone, e-mail (home and school)

- Current subject(s) that you are teaching

- Previous experience in ecology and research (courses taken, previous volunteer or paid experience, work done with students, etc.)

- You will be expected to use the training you receive back in your classroom during the follow school year. Please include a brief statement about what you intend to do, as far as you know.

Please briefly respond to these questions:

- How do you currently use internet resources in science classes?

- Please describe your experience teaching using research projects and community-based ecology projects.

Figure 2: Instructions for creating a model. (Credit to Teaching Ecological Complexity, 2009)

\section{Steps for creating your qualitative ecosystem model:}

Work alone on this part:

1. Think carefully about choosing the central two variables in your study. You might start with who eats whom. Then, think about 3 to 5 other main species, and abiotic factors, (both independent and dependent variables) that are relevant to your research study. You might ask: how does the weather affect the species involved? List these. Note down your reasoning for choosing these to use in your essay later.

2. Begin constructing the model starting with two main variables (biotic or abiotic components). Write the name of each component in its own circle or box. What is the relationship between these?

3. Qualitative models are typically drawn as familiar and intuitive 'signed digraphs' consisting of ecological 'components' (in boxes) and positive or negative 'links' (arrows). A component is any variable part of an ecosystem. For example, an ecosystem component could be a population of a given species, or the amount of nitrogen held in the soil, or the temperature of the water in a stream. Links are symbols that represent interactions occurring between components. These can be used to show a flow of materials or energy between components, or to indicate a causal effect of one component on another. The term 'system' refers to any combination of two or more components that have some form of interaction between them. Interactions between populations of different species in a community can be classified with combinations of the three symbols \{$, 0,+\}$. This modeling also uses a simple line for no effect or unchanged. 
4. Review the different types of qualitative symbols and interactions. Draw in the correct representative interaction.

5. Add the other 3-5 additional important components to the model one by one. As each component is added, think about how the component would interact with the components already entered into the model. An alternative method is to write each component on a separate index card, and connect them with pieces of string. This will allow you to move them freely until you are satisfied with the pattern. Then transfer the pattern to paper. Choose the symbol you think best describes the interaction. As interactions are added, decide which interactions seem to be significant and which seem more frivolous (e.g., while the body temperature of a deer may raise the temperature of the grass it naps on, this is probably going 'overboard' with information).

Figure 3: Pre and Post Modeling Essays (Credit to Teaching Ecological Complexity, 2009)

\section{Essays on model about your research project (beginning of project)}

Part 1: Work with a partner to use your model to explore the questions below that will be addressed in your written essay. You and your partner both need to have completed your own conceptual models of 2 central variables in your study, and 3-5 other organisms, plus abiotic variables that are important in explaining the pattern.

Part 2: After discussing your work with a partner, write an essay that responds to the following questions. The goal is to write your essay so that you have a well-explained model. Please put your name on the essay.

1. What are the main components of your model? Make sure each component of the model is labeled. Give your reason for including each one. Describe the relationships between these components by putting a number besides each arrow and logically explaining each number below the model. Make sure your explanation is as clear as possible. For example, "the sun negatively affects soil moisture by drying it out". What ecological process or processes does your model show?

2. Using your model, develop your research hypothesis. Briefly describe an experiment that will test both your model and your hypothesis and make a prediction of the outcome.

3a. Show feedback on your model itself using symbols and provide a written description of one feedback loop below.

3b. Choose one component in your system and describe a possible change over a short-term period of time. What effects can you expect on the other components of your model as a result of this change (indirect effects)? 


\section{Essays on model about your research project (end of project)}

Part 1: Work with a partner to use your model to explore the questions below that will be addressed in your written essay. You and your partner both need to have completed your own conceptual models of 2 central variables in your study, and 3-5 other organisms, plus abiotic variables that are important in explaining the pattern.

Part 2: After discussing your work with a partner, write an essay that responds to the following questions. Please put your name on the essay.

1. What are the main components of your model now? Make sure each component is labeled. Are they different from your first model? Give your reason for changing the ones that are different. Describe what you know now about the relationships between these components by putting a number besides each arrow and logically explaining each number below the model. What ecological process or processes does your model show?

2. Based upon the experimental results you have just completed and using your new model, develop a second research hypothesis that you would now conduct. Briefly describe an experiment that would test both your new model and your new hypothesis and make a prediction of the outcome.

3a. Show feedback on your model itself using symbols and provide a written description of one feedback loop below. Explain what you know about feedback loops that you didn't know before.

3b. Choose one component in your system and describe a possible change over a short-term period of time. What effects can you expect on the other components of your model as a result of this change (indirect effects)? What do you understand about indirect effects that you didn't know before? 
Figure 4: Rubric for Scoring Models (Credit to Teaching Ecological Complexity, 2009)

Part A: The model

Modeling Assessment Rubric

1- Scoring of conceptual model and description: Components (and descriptions)

Modeling Goal: Correctly identify specific components/variables of experiment and explain their importance to the research project.

\begin{tabular}{|l|l|}
\multicolumn{1}{|c|}{ Score } & \multicolumn{1}{c|}{ Examples } \\
\hline 0: Not score-able; no response. & "I don't know." \\
\hline 1 point: General ideas represented only & light, plants, animals \\
\hline 2 points: Components are mostly general & Sun, trees, animals \\
\hline $\begin{array}{l}\text { 3 points: Components somewhat reflect } \\
\text { the experiment }\end{array}$ & Plant productivity, \\
\hline $\begin{array}{l}\text { 4 points: Components accurately and } \\
\text { specifically reflect experiment }\end{array}$ & $\begin{array}{l}\text { Herbivore diversity, amount of carbon } \\
\text { dioxide, }\end{array}$ \\
\hline
\end{tabular}

\begin{tabular}{|l|l|}
\hline \multicolumn{2}{|l|}{ 2- Scoring of conceptual model and descriptions: Connections between variables } \\
\hline \multicolumn{1}{|c|}{ Modeling Goal: Show and explain the connections between variables } \\
\hline \multicolumn{1}{|c|}{ S: Not score-able; no response. } & \multicolumn{1}{c|}{ Examples } \\
\hline $\mathbf{1}$ point: One or two linear connections, errors & "I don't know." \\
\hline $\begin{array}{l}\mathbf{2} \text { points: Either too few or too many } \\
\text { (spaghetti strings) incorrect connections, some } \\
\text { correct, all have one or two steps (linear) }\end{array}$ & Willow $\rightarrow$ Hare \\
\hline $\begin{array}{l}\mathbf{3} \text { points: Many connections, all are } \\
\text { purposeful and correct, some complex with at } \\
\text { least two steps, some simple linear }\end{array}$ & Willow o $\rightarrow$ Hare o $\rightarrow$ Lynx \\
\hline $\begin{array}{l}\mathbf{4} \text { points: Many connections, mostly complex } \\
\text { and multi-stepped with three or more steps, } \\
\text { shows two-way interactions and possibly } \\
\text { cyclical interactions. }\end{array}$ & Nutrients $\rightarrow$ Willow o $\rightarrow$ Hare o $\rightarrow$ Lynx \\
\hline
\end{tabular}

\section{Part B: Rubric for Modeling Essay Questions}

Essay Question 1: Explain why you chose each component depicted. Describe the relationships or connections between all your components. What ecological process or processes does your model best depict?

Content Understanding Goal: Ecological diversity

\begin{tabular}{|l|l|}
\hline \multicolumn{1}{|c|}{ Level } & \multicolumn{1}{c|}{ Examples } \\
\hline 0: Not score-able; no response. & "I don't know." \\
\hline $\begin{array}{l}\mathbf{1} \text { point: Poorly applies diversity, very } \\
\text { general }\end{array}$ & $\begin{array}{l}\text { Interactions between biotic and abiotic } \\
\text { factors }\end{array}$ \\
\hline $\begin{array}{l}\mathbf{2} \text { points: Minimally applies one diversity } \\
\text { concepts }\end{array}$ & $\begin{array}{l}\text { The insect diversity in the meadow is } \\
\text { greater because of more moisture. }\end{array}$ \\
\hline $\mathbf{3}$ points: Adequately applies diversity & Meadows tend to have greater diversity of \\
\hline
\end{tabular}


concepts to research project

4 points: Shows mastery of diversity concepts, appropriately applies several

primary producers due to increased sunlight than forested site...

The presence of large woody debris may have more significantly impacted arthropod concepts to research project diversity than the absence of a canopy.

\begin{tabular}{|c|c|}
\hline \multicolumn{2}{|c|}{$\begin{array}{l}\text { Question 2: Develop hypothesis, (or re-write hypothesis) using components in } \\
\text { model. Describe how hypothesis (or secondary hypothesis) will be tested. }\end{array}$} \\
\hline Learning Goal: Understand how to develo & a testable hypothesis \\
\hline Level & Examples \\
\hline 0: Not score-able; no response. & "I don't know." \\
\hline 1 point: Poor & $\begin{array}{l}\text { The clear cut will better handle disturbance } \\
\text { because it has greater diversity. }\end{array}$ \\
\hline 2: Minimal, needs restructuring. & $\begin{array}{l}\text { What is the diversity in the meadow v.s. a } \\
\text { forest? }\end{array}$ \\
\hline 3: Adequately forms a testable hypothesis. & $\begin{array}{l}\text { How does log decomposition effect } \\
\text { arthropod diversity? }\end{array}$ \\
\hline $\begin{array}{l}\text { 4: Shows mastery in forming a clear, } \\
\text { testable hypothesis and describe method of } \\
\text { testing hypothesis. }\end{array}$ & $\begin{array}{l}\text { Species richness in fungivore arthropods } \\
\text { will be greater in the forest opening than } \\
\text { the forest. Measure species richness of } \\
\text { fungivore arthropods captured in forest } \\
\text { opening and in the forest at the same time. }\end{array}$ \\
\hline
\end{tabular}

\section{Essay Question 3: Discuss and illustrate feedback. Choose one component in your system and describe one change over short-term period. Describe any indirect effects you could expect. How could the patterns appear differently over longer time scales?}

Learning Goal: Understanding complexity in Ecosystems, show Feedback and trace through possible indirect effects

\begin{tabular}{|l|l|}
\hline \multicolumn{1}{|c|}{ Score } & \multicolumn{1}{c|}{ Examples } \\
\hline 0: not score-able; no response. & "I don't know." \\
\hline $\begin{array}{l}\text { 1: Poor understanding of feedback and } \\
\text { indirect effects, }\end{array}$ & $\begin{array}{l}\text { One example of feedback is the vegetation } \\
\text { in the meadow. }\end{array}$ \\
\hline $\begin{array}{l}\text { 2: Shows minimal understanding of and } \\
\text { application of feedback, minimal ability to } \\
\text { describe indirect effects, }\end{array}$ & $\begin{array}{l}\text { A change in arthropods would ricochet up } \\
\text { the food web and the entire ecosystem. }\end{array}$ \\
\hline $\begin{array}{l}\text { 3: Shows good understanding of and } \\
\text { application of feedback, but less proficient } \\
\text { describing indirect effects. Only describes } \\
\text { one plausible pattern of change (short term) }\end{array}$ & $\begin{array}{l}\text { Ecosystems function through varied array } \\
\text { of relationships that are usually nonlinear } \\
\text { and include many complex feedback } \\
\text { loops... }\end{array}$ \\
\hline $\begin{array}{l}\text { 4:Expertly understands and applies both } \\
\text { feedback and indirect effects (4 points). } \\
\begin{array}{l}\text { Describes plausible patterns of changes } \\
\text { over short and long time spans (4 points) }\end{array}\end{array}$ & $\begin{array}{l}\text { Feedback loops may have negative impacts } \\
\text { (competition) placing limits on growth of } \\
\text { herbivores...it may accelerate the rate of } \\
\text { growth of plants over the short term, but } \\
\text { due to feedback, not in the long term. }\end{array}$ \\
\hline
\end{tabular}


Figure 5: Teacher Practices Survey (Credit to Teaching Ecological Complexity, 2009)

\section{Teacher Practices Survey}

\section{Please answer the following questions based on what you have done for inquiry science in your course(s) this year.}

Briefly describe the student project(s) in ecology that your students have done this school year.

\begin{tabular}{|l|l|l|l|l|l|}
\hline $\begin{array}{l}\text { Indicate the degree to which students have done (or will } \\
\text { do) the following: }\end{array}$ & Never & Seldom & Sometime & Often & $\begin{array}{l}\text { Almost } \\
\text { Always }\end{array}$ \\
\hline 1. form a hypothesis & 1 & 2 & 3 & 4 & 5 \\
\hline 2. design a study & 1 & 2 & 3 & 4 & 5 \\
\hline 3. collect data. & 1 & 2 & 3 & 4 & 5 \\
\hline 4. $\quad$ enter data on spreadsheets & 1 & 2 & 3 & 4 & 5 \\
\hline 5. $\quad$ analyze data & 1 & 2 & 3 & 4 & 5 \\
\hline 6. interpret data & 1 & 2 & 3 & 4 & 5 \\
\hline 7. $\quad$ write research reports & 1 & 2 & 3 & 4 & 5 \\
\hline 8. present and discuss the meaning/importance of their results & 1 & 2 & 3 & 4 & 5 \\
\hline 9. $\quad$ work with an outside agency or scientist & 1 & 2 & 3 & 4 & 5 \\
\hline 10. learn about the environment and local ecology & 1 & 2 & 3 & 4 & 5 \\
\hline 11. learn that science is a way to raise questions and seek answers & 1 & 2 & 3 & 4 & 5 \\
\hline 12. go into the field to collect data related to questions they posed & 1 & 2 & 3 & 4 & 5 \\
\hline 13. conduct long term (2 or more weeks) experiments & 1 & 2 & 3 & 4 & 5 \\
\hline 14. work in teams to conduct field research & 1 & 2 & 3 & 4 & 5 \\
\hline 15. assess their own work using rubrics & 1 & 2 & 3 & 4 & 5 \\
\hline $\begin{array}{l}\text { 16. demonstrate their understanding about the relationship between } \\
\text { evidence and conclusions }\end{array}$ & 1 & 2 & 3 & 4 & 5 \\
\hline 17. learn ecology concepts & & & & \\
\hline $\begin{array}{l}\text { 18. learn how to draw an ecological model illustrating inter- } \\
\text { relationships. }\end{array}$ & 1 & 2 & 3 & 4 & 5 \\
\hline 19. use the internet (including the Ecoplexity website) to facilitate & 1 & 2 & 3 & 4 & 5 \\
\hline
\end{tabular}

Please describe how the summer workshop contributed to your teaching and student learning this year. 
Please describe any challenges/limitations that you faced in implementing a long-term ecology research project. Is there anything that could be done at future workshops (or during the school year) that could help to lessen these issues?

Do you have any final comments regarding the Ecoplexity workshop or website? 
Figure 6: Workshop Evaluation Survey (Credit to Teaching Ecological Complexity, 2009)

\section{Ecology Workshop Evaluation}

Directions: Please circle the number that best describes your agreement with the following statements.

As a result of my participation in the Teaching Ecosystem Workshop:

\begin{tabular}{|c|c|c|c|c|c|c|c|}
\hline 1) & $\begin{array}{l}\text { I am more knowledgeable than before } \\
\text { about ecology content }\end{array}$ & 1 & 2 & 3 & 4 & 5 & 6 \\
\hline 2) & $\begin{array}{l}\text { I am more knowledgeable than before } \\
\text { about carrying out field research }\end{array}$ & 1 & 2 & 3 & 4 & 5 & 6 \\
\hline 3) & $\begin{array}{l}\text { I plan to implement a unit where students } \\
\text { will conduct an inquiry based ecology field } \\
\text { research project }\end{array}$ & 1 & 2 & 3 & 4 & 5 & 6 \\
\hline 4) & $\begin{array}{l}\text { I plan to implement one or more of the } \\
\text { topics and/or skills I learned this week }\end{array}$ & 1 & 2 & 3 & 4 & 5 & 6 \\
\hline
\end{tabular}

Rate how well did the workshop prepare you for each of the following?

\begin{tabular}{|c|c|c|c|c|c|}
\hline & & & & & \\
\hline 5. Ability to use field research & 1 & 2 & 3 & 4 & 5 \\
\hline 6. Ability to utilize modeling & 1 & 2 & 3 & 4 & 5 \\
\hline Rate your satisfaction level for the following: & Very Poor & Poor & Fair & Good & Excellent \\
\hline $\begin{array}{l}\text { 7. Organization of the workshop (presentations, mix of } \\
\text { activities, etc.) }\end{array}$ & 1 & 2 & 3 & 4 & 5 \\
\hline 8. Presentations by instructors & 1 & 2 & 3 & 4 & 5 \\
\hline 9. Support from instructors & 1 & 2 & 3 & 4 & 5 \\
\hline 10. Field work experience & 1 & 2 & 3 & 4 & 5 \\
\hline $\begin{array}{l}\text { 11. Preparing you to incorporate the workshop } \\
\text { experience into your science course }\end{array}$ & 1 & 2 & 3 & 4 & 5 \\
\hline $\begin{array}{l}\text { 12. Meeting the goals you had for your own learning } \\
\text { about ecological complexity }\end{array}$ & 1 & 2 & 3 & 4 & 5 \\
\hline
\end{tabular}

What aspects of this workshop were most valuable and why?

We would appreciate any further comments you wish to share with us (use the other side of this page, if needed). 
Figure 7: Student Interest Survey (Credit to Teaching Ecological Complexity, 2009)

\section{Science Interest Survey}

Teacher's name:

Grade

School:

Check whether you are: A boy

or a girl

Do you speak spanish at home: YES

NO

We're interesting in finding out what you think about science. Read each statement, and then circle the response that best describes how true the statement is for you.

\begin{tabular}{|c|c|c|c|}
\hline 1. I think science at school is boring. & $\begin{array}{l}\text { Definitely NOT true } \\
\text { for me }\end{array}$ & $\begin{array}{l}\text { Sometimes true for } \\
\text { me }\end{array}$ & $\begin{array}{l}\text { Definitely TRUE } \\
\text { for me }\end{array}$ \\
\hline $\begin{array}{l}\text { 2. I enjoy talking to my friends and family about } \\
\text { what I'm learning in my life science class. }\end{array}$ & $\begin{array}{l}\text { Definitely NOT true } \\
\text { for me }\end{array}$ & $\begin{array}{l}\text { Sometimes true for } \\
\text { me }\end{array}$ & $\begin{array}{l}\text { Definitely TRUE } \\
\text { for me }\end{array}$ \\
\hline $\begin{array}{l}\text { 3. I enjoy learning about science by going } \\
\text { outdoors. }\end{array}$ & $\begin{array}{l}\text { Definitely NOT true } \\
\text { for me }\end{array}$ & $\begin{array}{l}\text { Sometimes true for } \\
\text { me }\end{array}$ & $\begin{array}{l}\text { Definitely TRUE } \\
\text { for me }\end{array}$ \\
\hline $\begin{array}{l}\text { 4. I think that working as a scientist would be an } \\
\text { interesting way to earn a living. }\end{array}$ & $\begin{array}{l}\text { Definitely NOT true } \\
\text { for me }\end{array}$ & $\begin{array}{l}\text { Sometimes true for } \\
\text { me }\end{array}$ & $\begin{array}{l}\text { Definitely TRUE } \\
\text { for me }\end{array}$ \\
\hline 5. When I go to college, I plan to major in science. & $\begin{array}{l}\text { Definitely NOT true } \\
\text { for me }\end{array}$ & $\begin{array}{l}\text { Sometimes true for } \\
\text { me }\end{array}$ & $\begin{array}{l}\text { Definitely TRUE } \\
\text { for me }\end{array}$ \\
\hline $\begin{array}{l}\text { 6. I have become more aware of the environment } \\
\text { because of my science lessons. }\end{array}$ & $\begin{array}{l}\text { Definitely NOT true } \\
\text { for me }\end{array}$ & $\begin{array}{l}\text { Sometimes true for } \\
\text { me }\end{array}$ & $\begin{array}{l}\text { Definitely TRUE } \\
\text { for me }\end{array}$ \\
\hline $\begin{array}{l}\text { 7. I think you can get along perfectly well in } \\
\text { everyday life without science. }\end{array}$ & $\begin{array}{l}\text { Definitely NOT true } \\
\text { for me }\end{array}$ & $\begin{array}{l}\text { Sometimes true for } \\
\text { me }\end{array}$ & $\begin{array}{l}\text { Definitely TRUE } \\
\text { for me }\end{array}$ \\
\hline $\begin{array}{l}\text { 8. I think it's important to study the local animals } \\
\text { and plants and their relationships }\end{array}$ & $\begin{array}{l}\text { Definitely NOT true } \\
\text { for me }\end{array}$ & $\begin{array}{l}\text { Sometimes true for } \\
\text { me }\end{array}$ & $\begin{array}{l}\text { Definitely TRUE } \\
\text { for me }\end{array}$ \\
\hline $\begin{array}{l}\text { 9. I would rather be given the right answer to a } \\
\text { science problem than to work it out myself. }\end{array}$ & $\begin{array}{l}\text { Definitely NOT true } \\
\text { for me }\end{array}$ & $\begin{array}{l}\text { Sometimes true for } \\
\text { me }\end{array}$ & $\begin{array}{l}\text { Definitely TRUE } \\
\text { for me }\end{array}$ \\
\hline $\begin{array}{l}\text { 10. I believe you can learn science in lots of places, } \\
\text { not only laboratories or classrooms. }\end{array}$ & $\begin{array}{l}\text { Definitely NOT true } \\
\text { for me }\end{array}$ & $\begin{array}{l}\text { Sometimes true for } \\
\text { me }\end{array}$ & $\begin{array}{l}\text { Definitely TRUE } \\
\text { for me }\end{array}$ \\
\hline $\begin{array}{l}\text { 11. I am more curious about the plants, animals, } \\
\text { earth and universe where I live because of my } \\
\text { science lessons. }\end{array}$ & $\begin{array}{l}\text { Definitely NOT true } \\
\text { for me }\end{array}$ & $\begin{array}{l}\text { Sometimes true for } \\
\text { me }\end{array}$ & $\begin{array}{l}\text { Definitely TRUE } \\
\text { for me }\end{array}$ \\
\hline $\begin{array}{l}\text { 12. I believe that what is known about a scientific } \\
\text { field like ecology changes as scientists come up } \\
\text { with new ideas from their experiments. }\end{array}$ & $\begin{array}{l}\text { Definitely NOT true } \\
\text { for me }\end{array}$ & $\begin{array}{l}\text { Sometimes true for } \\
\text { me }\end{array}$ & $\begin{array}{l}\text { Definitely TRUE } \\
\text { for me }\end{array}$ \\
\hline $\begin{array}{l}\text { 13. I like trying to find the answers to scientific } \\
\text { questions by doing experiments, collecting data, } \\
\text { and interpreting the meaning of the data. }\end{array}$ & $\begin{array}{l}\text { Definitely NOT true } \\
\text { for me }\end{array}$ & $\begin{array}{l}\text { Sometimes true for } \\
\text { me }\end{array}$ & $\begin{array}{l}\text { Definitely TRUE } \\
\text { for me }\end{array}$ \\
\hline $\begin{array}{l}\text { 14. I enjoy learning science from guests who visit } \\
\text { our classroom and help our teacher with science } \\
\text { lessons }\end{array}$ & $\begin{array}{l}\text { Definitely NOT true } \\
\text { for me }\end{array}$ & $\begin{array}{l}\text { Sometimes true for } \\
\text { me }\end{array}$ & $\begin{array}{l}\text { Definitely TRUE } \\
\text { for me }\end{array}$ \\
\hline & & & \\
\hline
\end{tabular}




\section{Figure 8: Workshop Schedule}

Teaching Urban Watershed Ecology: Schedule: July 2009, BES-PSU

Before the workshop: Teachers will be given background information about the workshop topics and will choose which project they will focus on

Day 1: Introduction/Designing a Study/Intro to Qualitative Modeling Zenger Farms \& Field Sites (Brookside, Kelly, Glencoe)

- 9:00-9:30 Welcome, introductions, overview of Ecoplexity project [Marion/Kala]

- 9:30-10:00 Presentation about Bioswales/Wetlands- Ted

- 10:00-10:45 Presentation about Water Chemistry- Lynn/Megan

- 10:45-1:00 Travel to sites, visit field site to generate ideas about key factors, begin formulating hypothesis, lunch, drive back to Zenger farms

- 1:00-2:30 Presentation about Macroinvertebrates- Patrick

- 2:30-2:50 Discuss modeling, do example together [Kala]

- 2:50-3:15 Begin model, identify components to include [Kala]

- 3:15-3:45 Think-pair-share about model and hypothesis [Kala]

- 3:45-4:30 Complete 1st model and questions [Kala]

- 4:30-5:00 Complete required forms, pre-evaluation questionnaires, Debrief day-write what went best, what wasn't clear [Kala]

- Homework: Read article related to project and become more familiar with protocols, solidify hypothesis and research question

Day 2: Collect data

Zenger Farms \& Field Sites (Brookside, Kelly, Glencoe)

- 9:00-9:20 Morning activity: Teachers share example lessons from past years if available [Kala]

- 9:20-10:05 Share, solidify hypothesis and research question [Kala]

- 10:05-10:15 Break

- 10:15-10:45 Discuss article [Kala]

- 10:45-1:00 Drive to sites, discuss data collection tools (what will be used, what data will be collected, how it will be recorded) and methods, lunch [Ted-swales; Megan/Lynnchem]

- 1:00-4:00 Practice with tools/protocol, collect data, drive back to Zenger farms [Tedswales, Patrick-macros]

- 4:00-4:30 Revisit $1^{\text {st }}$ model and hypothesis, write down reflections (learning, change) [Kala]

- 4:30-5:00 Debrief day-write what went best, what wasn't clear [Kala]

- Homework: Review data analysis tools on website

\section{Day 3: Analyze Data}

PSU

- 9:00-9:20 Morning activity: Share examples from past workshops (Teacher research) [Kala]

- 9:20-10:00 Enter field data [Kala]

- 10:00-10:10 Break

- 10:10- 11:10 Introduce statistical analysis tools (using website) [Marion/Kala]

- 11:10-12:10 Begin to analyze data [Marion/Kala]

- 12:10-1:10 Lunch

- 1:10-2:10 Continue to analyze data [MarionKala] 
- 2:10-2:20 Break

- 2:20-3:00 Discuss feedback and indirect effects (in relation to teachers' projects) write down reflections on own model (learning, change) [Marion]

- 3:00-4:00 Begin to interpret results [Kala]

- 4:00-4:30 Revisit model, write down reflections (learning, change) [Kala]

- 4:30-5:00 Debrief day-write what went best, what wasn't clear [Kala]

- Homework: Read article about reflective learning, Write up ideas on integrating their project into the classroom and parts of the website they will use.

\section{Day 4: Interpret Results/ Research Poster}

PSU

- 9:00-9:20 Morning activity: Share examples from past workshops (student research)[Kala]

- 9:20-9:50 Discuss reflective learning article [Kala]

- 9:50-10:00 Break

- 10:00-10:40 Discuss components of a research poster (using website), how to find sources, examples [Kala]

- 10:40-12:00 Finish interpreting results [Kala]

- 12:00-1:00 Lunch

- 1:00-4:00 Begin scientific research, poster compilation [Kala]

- 4:00-4:30 Scheduling of student projects, continue write up of ideas for classroom project [Lynn/Megan/Kala]

- 4:30-5:00 Debrief day-write what went best, what wasn't clear [Kala]

- Homework: Finish research poster, finish write up of classroom project ideas

Day 5: Presentations/Application to classroom Zenger Farms \& Field Sites (Brookside, Kelly, Glencoe)

- 9:00-10am Presentation of Research Posters [Lynn, Megan, Kala]

- $\quad$ 10-12 Create $2^{\text {nd }}$ model, think-pair-share, answer modeling questions, discussions of $2^{\text {nd }}$ model (interview questions) [Kala]

- 12-12:50 Lunch/Diack presentation

1-1:45 Share ideas for integration of project into the classroom, show maps of possible sites for teachers

- 1:45-2:00 Any additional assessments, wrap up 
